\title{
Professor Jan J. Kellerman - (1926-1993)
}

It is just 10 years since I first met Jan Kellerman at an international meeting in Jerusalem. One could not help being impressed by his intellect, his broad knowledge of the literature, his insatiable desire to explore new areas, and the respect which he commanded from his colleagues and trainees. However, there was another aspect of Jan's character which impressed me then and even now after his untimely death: Jan had a warmth and charm to his personality which radiated from him and touched all those who came into contact with him. In novels and plays set in central Europe, one recognizes this character trait, it is truly Old World charm.

Jan was born in Bratislava, Czechoslovakia, in 1926. His father was a well-known champagne vintner, undoubtedly an important

factor in Jan's sophistication. He was a bright student who entered medical school in 1947 following a five-year hiatus in his education, a result of the horrors of the Holocaust. In 1955 he graduated from the Leopold Franzens University Medical School in Innsbruck, Austria. He emigrated to Israel and trained in internal medicine at the Tel Hashomer Governmental Hospital, later to become the Chaim Sheba University Hospital. These were difficult times for the fledgling state of Israel: Jan served his country for three years as Commander of the Israeli Army Hospital of the Southern Command. Following military service, he returned to Tel Hashomer specializing in Cardiology at the Heart Institute, where he developed his life-long interest in cardiac rehabilitation and exercise physiology. Follow-

1

ing completion of his cardiology training, he was named Head of the Cardiac Rehabilitation Institute at the newly constituted Chaim Sheba University Medical Center.

Two years ago, he retired as the Director of this Institute, but Jan was not one to go quietly into retirement. In fact, he accepted two new challenges, the Directorship of the newly founded Ringers Unit for Clinical Cardiac Research at the Chaim Sheba Medical Center and the Editorship of a new Karger journal, Exercise Cardiology. We corresponded about these new ventures, and I know how excited he was by the intellectual and administrative demands of these two new projects.

Jan was particularly fond of his work in the publishing world. He wrote fluently in English, German, and Hebrew and was an Editor of international repute. In 1979, he assumed the Editorship of Cardiology, a job which he performed with skill and tact until his retirement in 1991. He was a member of the editorial boards of numerous scientific journals as well as Book Series Editor of Advances in Cardiology. He published more than 200 scientific articles, book chapters, book reviews, and abstract

$\mathrm{s}$ and

edited 15 books and monographs.

Jan was a stimulating teacher and lecturer who was much in demand at international meetings around the world. He was a Fellow of the American College of Cardiology, the American College of Chest Physicians, the Council on Clinical Cardiology of the American Heart Association, the European Society of Cardiology, the Israeli Heart Society, and the Council on 
Geriatric Cardiology. From 1985 until his death, he was Clinical Professor of Cardiology at the Sackler School of Medicine, Tel-Aviv University.

Intellectual curiosity was one of the hallmarks of Jan's character. He actively participated in all of the scientific work of his Institute in addition to serving as a principal investigator for a number of multicenter trials. He was frequently a consultant to the WHO Advisory Committee on Cardiovascular Diseases.

On a personal note, Jan was a charming and warm host and friend. In their apartment in RamatGan, Jan and his wife, Erika, an Auschwitz survivor, recreated the sophisticated and cozy atmosphere of central Europe although with a modern Israeli twist. Jan was very knowledgeable about wines, undoubtedly the re-

\footnotetext{
Alpert

Obituary

suit of his upbringing in the home of a renowned vintner. His wine selections, Erika's wonderful food, and the delightful conversation made an evening at the Kellermans' a night to be remembered.

I was greatly saddened by Jan Kellerman's premature death. The Cardiology community will miss his intellect and his organizational talents; I will miss a good friend.

On behalf of all the Karger family, Thomas Karger

I can only agree with everything Dr. Alpert said, but I would also like to add a few heartfelt words, and express my feelings of admiration and respect for Jan Keller-man, that grew during our many years of cooperation in publishing.

Not only did I hold his work in highest esteem, but I also appreciated our warm and friendly relationship: my family and I had grown very fond of Erika and Jan. It is hard for us to realize that we will have to do without his company, his charm, and his advice; we will miss the memorable times we spent with him and his wife. My family and I will, however, continue to cherish our friendship with Erika and will always keep in touch.

W. We also hope that her unfailing devotion to the welfare of those who need her will give her the strength to overcome this tragic loss; her many friends

former patients and all
} 